\title{
LOST AND FOUND
}

\section{Gabby Malpas and Pam McKinlay}

Gabby Malpas graduated from the Dunedin School of Art in 1986 and has gone on to have a successful international career in ceramic design and decoration. Next year she will be returning to Dunedin with a solo exhibition and will be holding artist workshops and seminars to share her experience and expertise. The exhibition will be at the Dunedin Botanic Garden, a major source of inspiration for her while at art school in 1984-86.

This is the story of how the Art School came back into contact with one of its graduates through the good offices of social media and discovered one of our own as the brush-holder behind some of the most world's most beloved contemporary table ceramics.

\section{“I BELIEVEYOU HAVE MAIL FOR ME” - PAM MCKINLAY}

To set the scene, we were in the weeks following the 15 March 2019 mosque attacks in Ōtautahi Christchurch. A bill banning semi-automatic weapons was being fiercely debated,' with partisans lining up in pre-subscribed seats. Our Prime Minister Jacinda Ardern called on tech giants to step up and take steps to prevent online platforms being used to promote extremism and hate speech, which had resulted in an unprecedented act of local terrorism in New Zealand. ${ }^{2}$ The nation was in shock and a state of mourning. Facebook came under scrutiny from all sides and faced a massive backlash from its members, many deciding that "enough was enough" and they would have no part in supporting it into the future. ${ }^{3}$ As a social media administrator, I was witness to the "Facebook Blackout," a 50-hour protest against Facebook and other social media platforms. ${ }^{4}$ Page visits declined, and followers fell off.

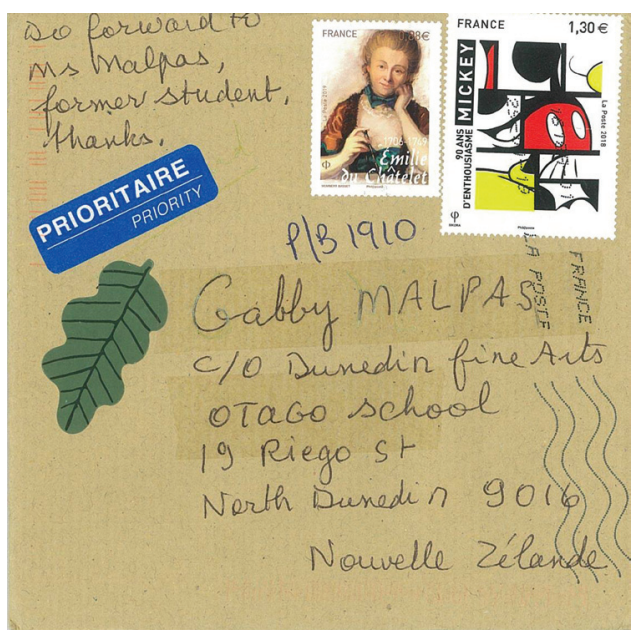

Figure I. A letter addressed to "Gabby Malpas c/- Dunedin Fine Arts" arrived March 2019.

Into this troubling milieu a letter came to me from our student coordinator with the request, "Can you put up a post to see if we can locate this alumnus we've lost track of?" I noted the postmark (from France) and the handwriting on the envelope, which looked as though it had been scribed by an elderly hand and posted a photograph of the letter on the Dunedin School of Art Facebook page. "We are looking for Gabby Malpas - can we can get this letter to her?" In the current climate I didn't hold out much hope.

The next morning, I noticed that this post had become a 'rock star' post on our page, and by the end of the week it had accumulated over three and a half thousand views, shares and comments. Among the 'good luck' wishes and reminiscences were clues as to where we might continue our search for the letter's intended addressee. 
I followed up the most likely comments and then, among the next set of replies, I read: "Hello there - I am Gabby Malpas ... I believe you have some mail for me?"

Gabby had graduated in 1986, majoring in ceramics, studying under several tutors including Neil Grant. She was delighted when I sent her a photo of Neil, who I share an office with. Gabby responded: "33 years since I left the place - [he's] looking as fabulous as ever. His words ring in my ears every day - 'you gotta draw every day', was his mantra ... and oh how l'm trying to stick to it."

Like all those who had followed the original post, I was curious to see how the story of the letter's journey ended. Gabby replied (abridged):

"Thank you and Neil Grant for sending me the letter. I got it yesterday ... There is an address, so I will be writing to the sender this week.

It was sent in January, from a woman who saw my art on cards that I have licensed to a company in France. She is very ill. She has no internet and by the sounds of things life is tough, so even more remarkable that she found the time to send this gorgeous note and even a little scented sachet."

And later:

"Hey all ... here's the latest update ... on Friday I received a reply from [name withheld] in the post. She's really not in a good way, but my post gave her some cheer. She lives in rural France and is old school, so snail mail is the way we will communicate ... so I guess we are penpals now. I told her how she has a number of Internet fans now who send her their best wishes."

I followed the links that Gabby had sent me of her work and was surprised to see that her artwork is used for the designs on the Maxwell \& Williams range of tableware, which I was familiar with. Gabby's paintings are licensed to a number of luxury designer

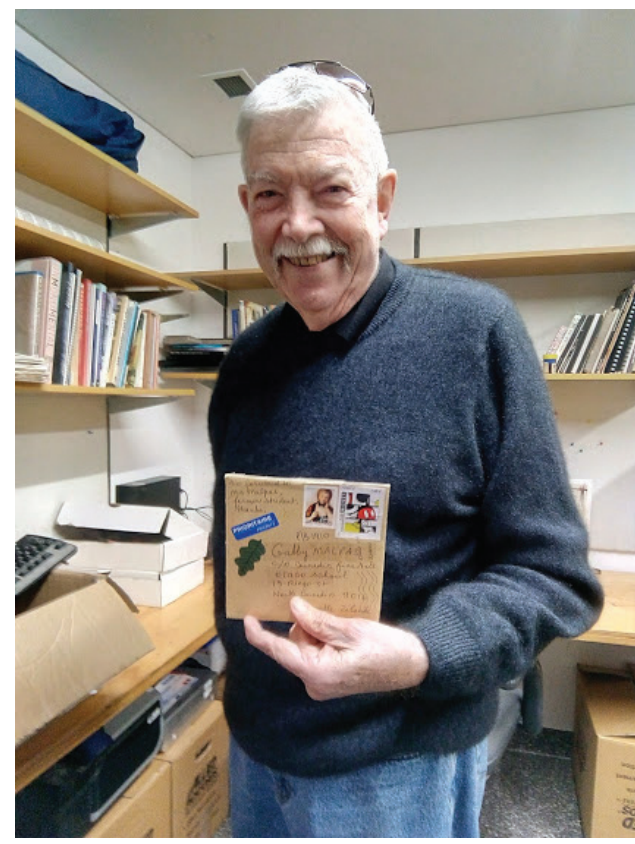

Figure 2. Neil Grant, Gabby's former tutor and emeritus lecturer in the Ceramics Department, still has a presence at the Dunedin School of Art. Photo: Pam McKinlay, April 2019. brands. These include Arocolor, based in Shanghai, agents for original artwork and licensed designs for use on textiles for soft furnishings, umbrellas, tablecloths and throws (their website is in English, Chinese and Arabic); Maxwell \& Williams (tableware); One Kings Lane (giclée prints); Great Big Canvas (licensed wall art); Blue Island Press, Australia, (retailing gift cards and stationary); Editor Gift and Cards (gift cards and wrap); Pacmat, UK (picnic rugs); and Utterly Art LLP, (Singapore). Her original paintings are intricately observed watercolours, botanical studies of flora set amid still-life arrangements of ceramics, often with distinctive Chinese decoration. To each painting she adds birds and butterflies and sometimes sea creatures. As one looks closer, whimsical elements reveal themselves - for me, these surprises included a coral in a garden arrangement, hidden insects in tree branches. I was amazed at the scale of her output, and where and how it was being used in contemporary commercial design. And so, our conversations continued. 


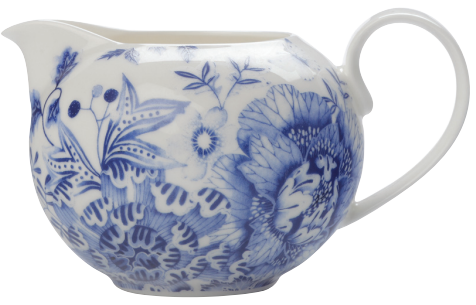

Figure 3. Maxwell \& Williams

Toile de Fleur tea service accessories (20।8).

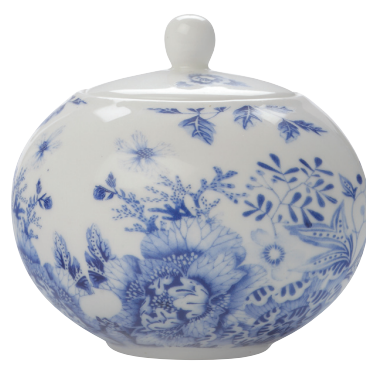

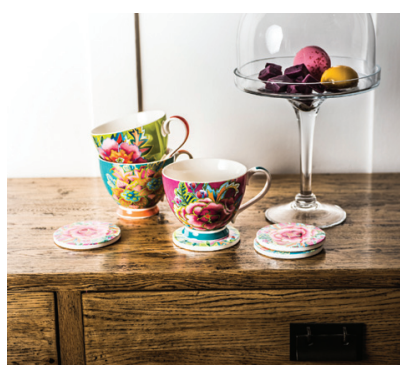

Figure 4. Maxwell \& Williams Hanoi range (20|6).

\section{PRACTICE PERSPECTIVE - GABBY MALPAS}

\section{Introduction}

My name is Gabby (Gabrielle) Malpas - it was given to me by my adoptive parents when they adopted me in Auckland in 1966 at ten days old.

I am ethnically Chinese and a citizen of New Zealand, Australia and the UK.

Between 1984 and 1986 I studied at the Dunedin School of Art for the three-year Diploma in Fine Arts. I majored in ceramics and studied under Bronwen Cornish, Michael Trumic, Christine Boswijk, Lawrence Ewing and Neil Grant. I honestly can't remember why I decided to major in ceramics, but I remember school excursions to the Crown Lynn factory in Auckland and thinking how cool it was, while the rest of the class were bored witless. For me, ceramics is a slow art - it takes years to become a master and often you don't ... Patience and a methodical process are requirements - which in hindsight were probably difficult for me at that stage of life but are at the core of my art practice now.

When I first started throwing on the wheel - progressing to bowls and vase shapes - Michael Trumic remarked that my forms were classic Han Chinese. I was like, "Get outta here." As an adoptee raised in a white home in the 60s, 70 s and 80s - when anti-Chinese immigration policies were still a recent memory - all I wanted to do was fit in. I paid no attention to classic Chinese art and the gorgeous, delicate porcelain wares in museums that I make a beeline for now. I was trying to emulate the rough-hewn, dug-out-of-a-hillside, organic, sculptural (but mostly brown) shapes that the other ceramicists were producing - work that I admired and still do. But I liked colour, and so I started making majolica works because I could paint pictures on them.
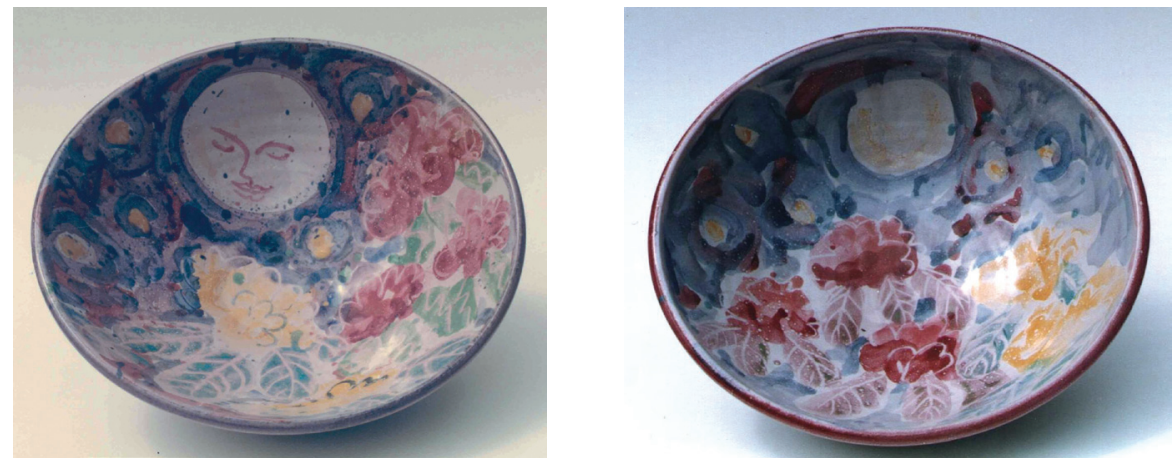

Figure 5 and 6. Majolica ware made by Gabby Malpas during her student days at Dunedin School of Art, 1986. 


\section{Finding my mojo}

I always wanted to be a professional artist, and my parents had always envisaged me as somehow being one. But I had to pay he rent and eat, and so I embarked on a corporate career in the UK after following the herd to London in 1988. (Much later, I found myself in Australia and settled there in 2003.) I devised a life plan - to work three days a week and paint for four ( 1 switched to painting after leaving Dunedin). Neil Grant's words to me in the last term of 1986 are still relevant and kept me grounded: "You need to draw every day."

Making art around a day job is an important goal to aim for, but it is also inhibiting - I exhibited as regularly as I could and kept making art at night and on weekends, but I knew I had a long way to go. In Australia I started working my way out of the corporate world to spend more and more time painting (and building up a library of images for licensing), until finally in 2019 I reached a point where could concentrate solely on my art career. I spent years refining my technique, but also developing my distinctive style, a curious and unique blend of Western and Asian art. I also apply my skills as a digital project manager in my own art practice, which makes working on commissions and corporate projects a lot easier and less stressful for everyone involved - so I am grateful for that.

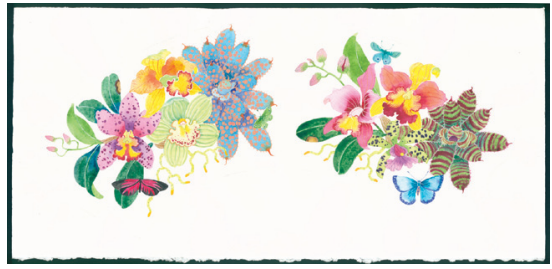

Figure 7. Gabby Malpas, orchid design (2017) original artwork for the

Maxwell \& Williams Exotica range.

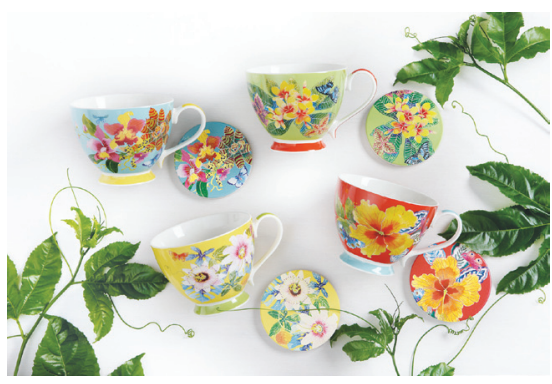

Figure 8. Maxwell \& Williams' Exotica range, design by Gabby Malpas (2017).

One good thing about living in the UK was that I had access to some of the finest art collections and museums in the world. I studied how things were made at first hand and began to appreciate the techniques and skills of the makers.

I came to realise that time is an important factor in making art. I have always admired those artistic prodigies who found success and fame very early in their careers. Of course, there is always a touch of jealousy here, but I have come to understand that I needed to work through so many things to finally arrive at - and embrace - a style that for many years I stifled in order to 'fit in.' It's taken me decades rather than years to get to a point where I am satisfied with my work - but I also know there are a few more decades of learning and refining to go ...

\section{Finding my own narrative}

Fast forward to 2020 - I was 54 in March. I am a professional, exhibiting and licensed artist, with work in private and public collections all over the world. I license work globally to companies producing a range of products. One of my contracts is with Australian homewares company Maxwell \& Williams, with whom I have collaborated on several tableware projects. It is a dream of mine to one day make ceramic pieces again - but for now, I satisfy myself with producing imagery for commercial products, knowing they will reach a much bigger audience.

I work on paper and canvas: producing unashamedly lavish, colourful and detailed images of flora and fauna, but often incorporating stories that make you think or look twice. Meeting my birth mother in 2004 led me to understand that I am 100 percent Chinese and encouraged me to celebrate my heritage through my work. As a Chinese adoptee, I am challenging the centuries-old and very European tradition of chinoiserie with my own alternative narrative.

I think I am qualified. 




Figure 9. Gabby Malpas, Toile de Fleur design (2018) original artwork for Maxwell \& Williams' Exotica range.

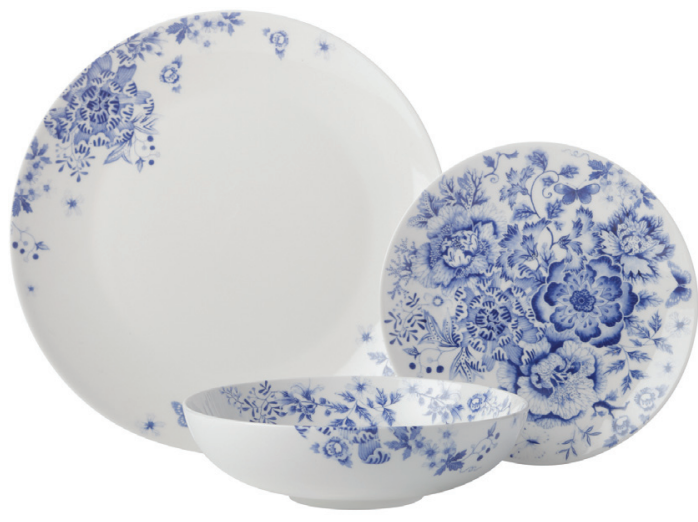

Figure I I. Maxwell \& Williams'Toile de Fleur range (20 I 8), design by Gabby Malpas - plates.

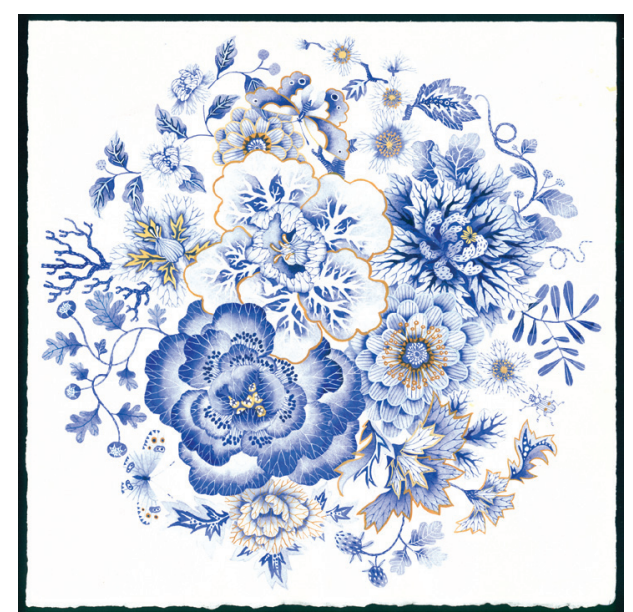

Figure 10. Gabby Malpas, Toile de Fleur design (2018) original artwork for Maxwell \& Williams' Exotica range.

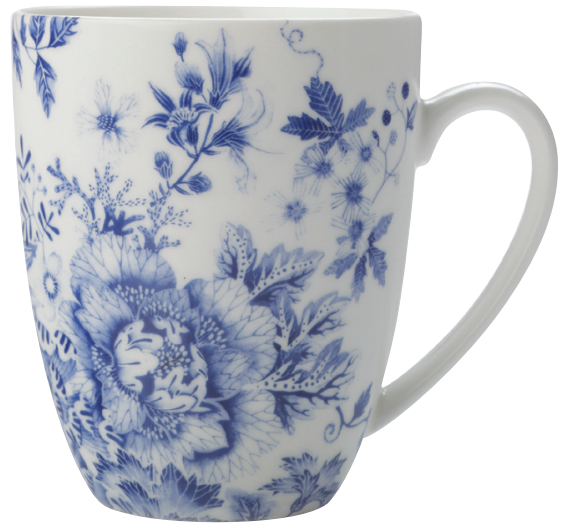

Figure 12. Maxwell \&Williams'Toile de Fleur range (2018), design by Gabby Malpas - mug.

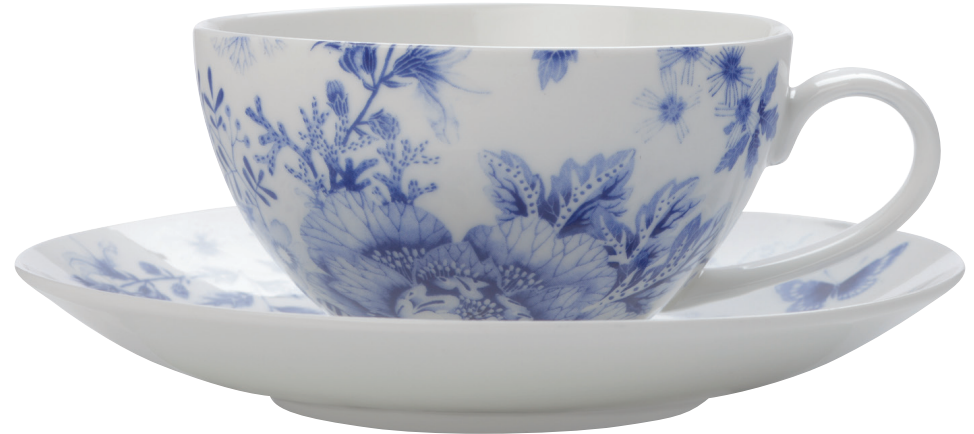

Figure 12. Maxwell \& Williams'Toile de Fleur range (20 I8), design by Gabby Malpas - cup and saucer. 


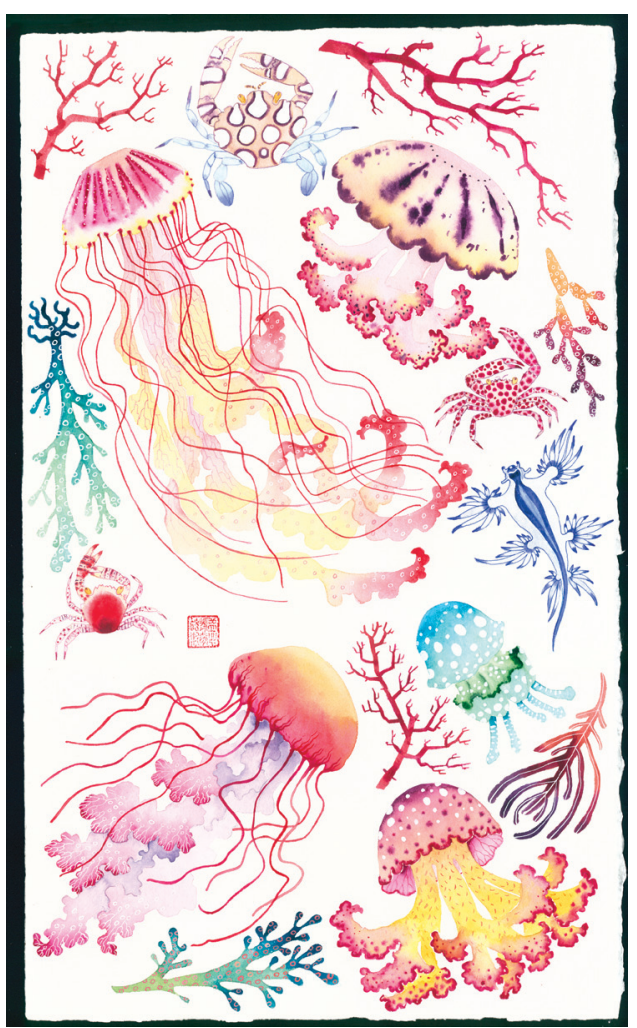

Figure 13. Gabby Malpas - original artwork for Arocolor sea umbrella.

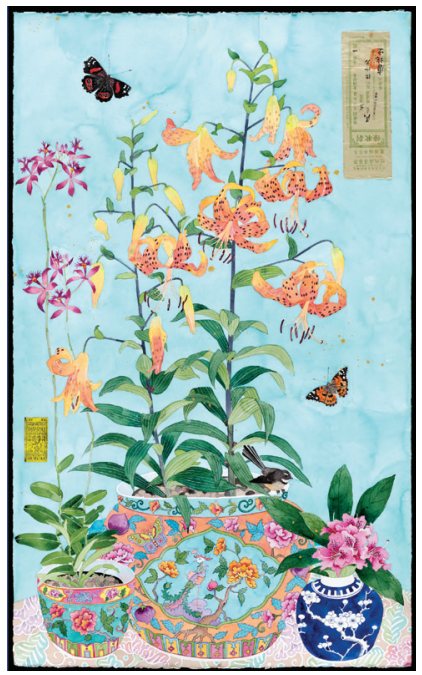

Figure 16. Gabby Malpas, "Tigermum," 2017, original artwork for Arocolor cushions.

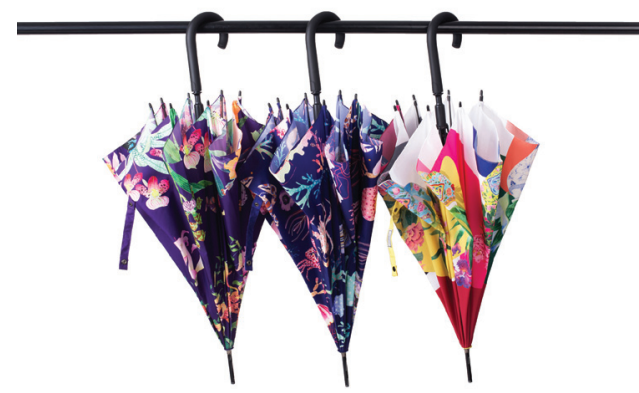

Figure 14. Arocolor umbrellas.

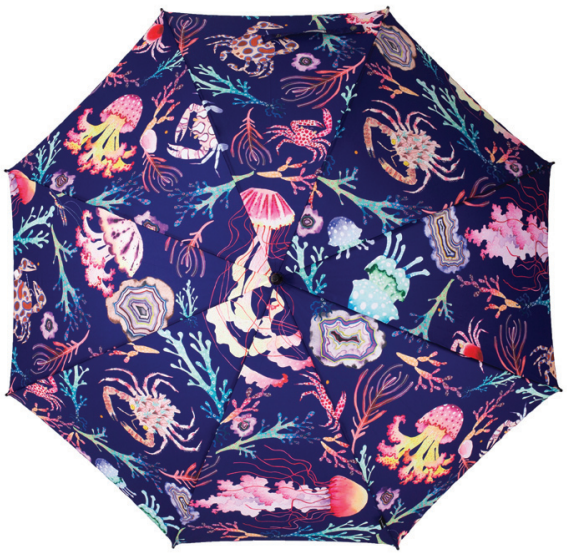

Figure 15. Arocolor umbrella - "Listening to the Sea.'

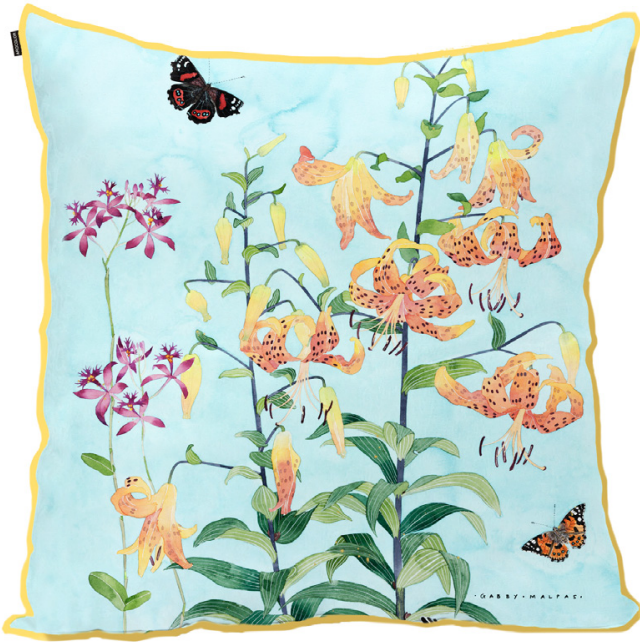

Figure 17 Arocolor cushions - "Tigermum" design (2017). 


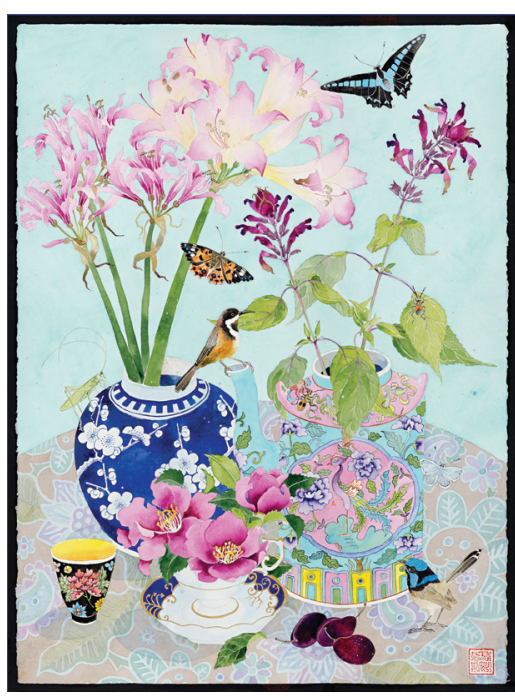

Figure 18. Gabby Malpas, "Tigermum," 2017, original artwork for Arocolor cushions (pink).

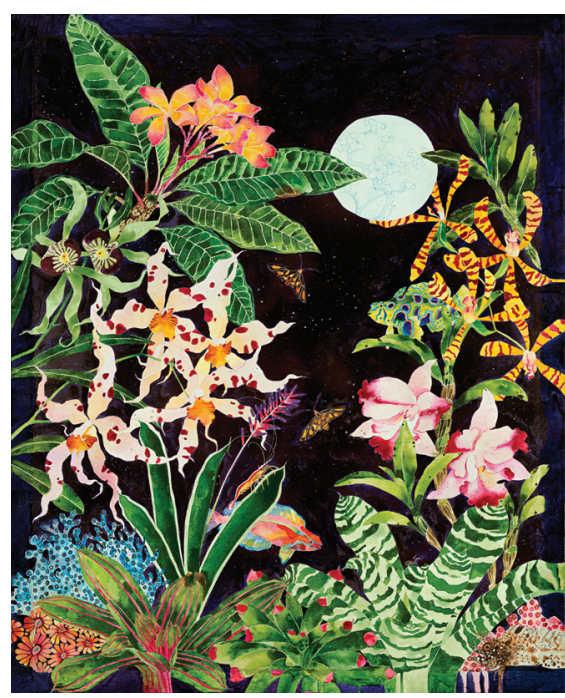

Figure 19. Gabby Malpas, original artwork for the Arocolor summer 2020 range.

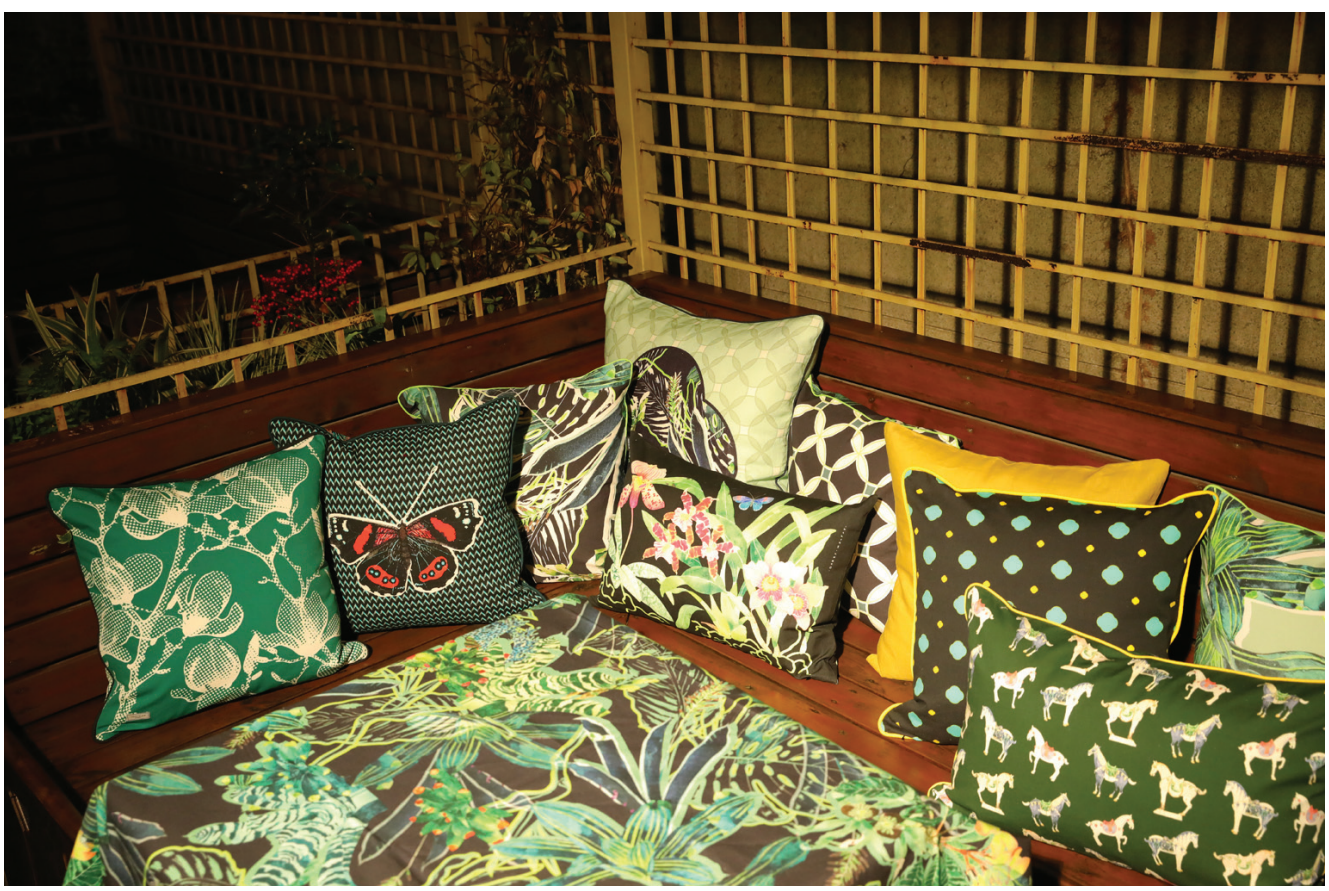

Figure 20. Arocolor's summer 2020 range, designs by Gabby Malpas. 


\section{Gabby Malpas, “The Painted Garden Exhibition,” Dunedin Botanic Garden, 202I}

I spent a lot of time in the Dunedin Botanic Garden as a student - it was an easy cycle or walk from my student flats in Union Street and later Cumberland Street. My favourite places were the Upper Garden in springtime when the trees would be in blossom, and the Rhododendron Dell with its fabulous showy blooms, with private spaces for sitting underneath.

I studied many of the plants, flowers and fungi I found there, and being a temperate garden, I found the same species in gardens all over the UK. Dunedin also has a beautiful twilight - much the same as in the UK - that you don't get in Auckland or Sydney. Those early summer evenings spent in the botanic garden before the gates closed were magical.

It took me years to learn to capture flora in the way I wanted - a lot of drawing and looking. I am delighted to be returning to Dunedin to show work for the first time since graduating from the Dunedin School of Art in 1986.
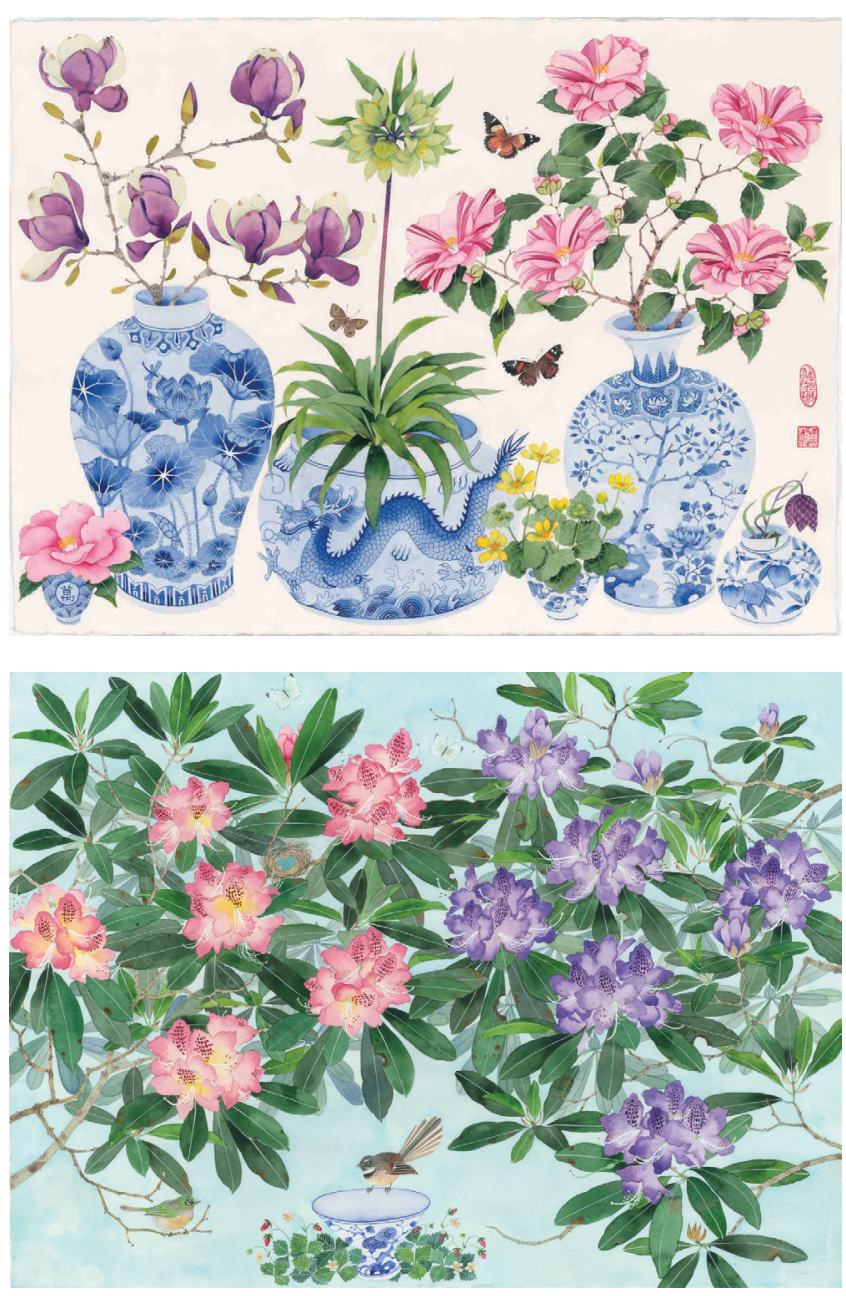

Figure 21. Gabby Malpas, Garden in Pots, 2020,

watercolour and gouache on Arches paper, $76 \times 57 \mathrm{~cm}$,

"The Painted Garden Exhibition," 2020.

Figure 22. Gabby Malpas,

Rhododendron Dell,

2020, $76 \times 57 \mathrm{~cm}$,

"The Painted Garden Exhibition," 2020. 


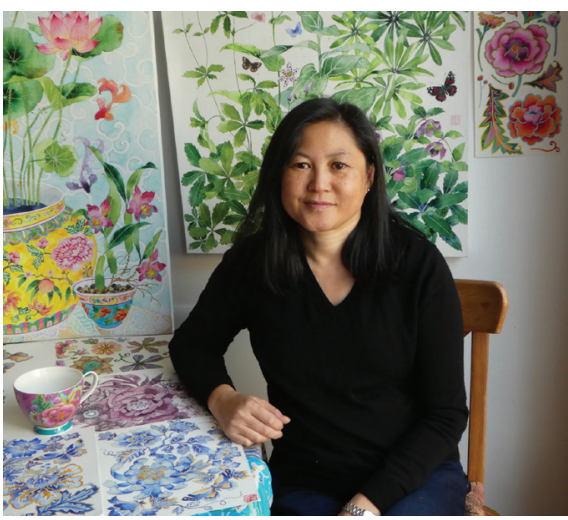

Figure 23. Gabby Malpas at home in Sydney, 2020.

\section{EPILOGUE - PAM MCKINLAY}

This has been the story of how I 'met' Gabby. Gabby and friends continue to stay in contact with [name witheld]. Gabby has touched our lives with her generous spirit in so many ways. We also share this story of how a small village of people on keyboards reached out from across the world to deliver a letter to rural France, to show another side of social media. I hold onto that thought as we navigate the thoroughfares of Facebook I am grateful for stories that can unite us to help each other if we seek to do so. In this story of "Lost and Found," new friendships have been formed and old connections renewed. I am looking forward to the next chapter of this unfolding tale when Gabby Malpas visits Dunedin in 2021.

Gabby Malpas is an alumni the Dunedin School of Art. She has exhibited internationally in Singapore, Shanghai, Hong Kong, London, Australia and in New Zealand and been a finalist in many of Australia's top Art Awards. In her work she challenges the genre of Chinoiserie with her own narrative.

whatsapp: +6I 423470831

www.gabbymalpas.com

instagram: @gabbymalpas

Facebook: Gabby Malpas - Artist

Pinterest: Gabby Malpas

Pam McKinlay (@ORCID No 0000-0002-1731-6437) works part-time for the Dunedin School of Art and Research Office at Otago Polytechnic. She has an academic background in applied science and history of art and is an artist who is a maker predominantly in weaving, ceramics and photography.

I "2019 Firearm Law Changes (Arms Amendment Bill 2)," New Zealand Police, https://www.police.govt.nz/advice-services/ firearms-and-safety/firearm-law-changes-prohibited-firearms.

2 "Christchurch Call Outcome is a Vital First Step in Addressing Terrorism and Violent Extremism Online," InternetNZ, I6 May 2019, https://internetnz.nz/news/christchurch-call-outcome-vital-first-step-addressing-terrorism-and-violent-extremismonline.

3 Phil Taylor, "Facebook to Clamp Down on Hate in Response to Christchurch Mosque Attack," New Zealand Herald, 30 March 2019, https://www.nzherald.co.nz/nz/news/article.cfm?c_id= | \&objectid= | 2217577.

4 Caroline Fleming, "Tauranga Woman to Lead 50-hour Facebook Blackout for Christchurch Massacre Victims," New Zealand Herald, 19 March 2019, https://www.nzherald.co.nz/nz/news/article.cfm?c_id= | \&objectid=|22 | $4 \mid 54$. 